\title{
Firm heterogeneity and the market scope of European multinational activity
}

\author{
Maite Alguacil. Department of Economics and Institute of International Economics, \\ Universitat Jaume I, Castellón (Spain). E-mail address: alguacil@uji.es.
}

Josep Martí. Department of Economics, Universitat Jaume I, Castellón (Spain). E-mail address: arnauj@uji.es

Vicente Orts. Department of Economics and Institute of International Economics, Universitat Jaume I, Castellón (Spain). E-mail address: orts@uji.es

\begin{abstract}
This paper examines the relationship between the characteristics of European firms and the market scope of their international activity. We show, theoretically, that when markets can be served by exports or through foreign affiliates, a strict hierarchy of firm characteristics and the number of markets they invest in or exports can only be established for firms engaged in foreign direct investment (FDI), but not for exporters. Empirically, our findings confirm the significant role of firm heterogeneity in the structure of European international activity, as well as the increasing relationship between firm characteristics and the number of markets in which they operate. Additionally, in line with our predictions, the estimates reveal the existence of heterogeneous effects and non-linearities in this relationship, with important differences between exporters and firms engaging in FDI.
\end{abstract}

Key words: Firm heterogeneity; Location choice; Internationalization strategy; Export; FDI; Market scope

JEL classification: F14; F21; F23; D24 


\section{Introduction}

It is widely accepted that the internationalization performance of firms is related not only to the host country features, but also to the firms' own characteristics. Several works have emphasized the role of firm heterogeneity in their internationalization structure. According to this literature, increasing the complexity of the internationalization strategies, such as moving from domestic sales to foreign selling or from exports to FDI, will entail higher costs, and so only those firms that can afford them will be able to engage in more complex internationalization strategies (Bernard and Jensen 1999; Melitz 2003; Helpman et al. 2004). ${ }^{1}$ Exporting firms incur in additional fixed costs of exporting and variable costs of transportation and distribution that are not assumed by firms that sell only in the domestic market. Yet, if a firm decides to avoid these variables costs of exporting, by opening a foreign affiliate, it should assume the higher fixed costs associated with opening and managing a foreign affiliate. ${ }^{2}$ These facts explain why firms that invest abroad are more productive than firms that just export and why firms that only sell their products domestically are less efficient than exporters. Numerous empirical studies indeed provide evidence relating the internationalization status of firms with their own characteristics (Bernard and Jensen 1999; Head and Ries 2003; Girma et al. 2005; Tomiura 2007; Martí el al. 2015).

But the complexity of the internalization strategies also extends to the number of foreign markets where firms are active (Barba-Navaretti et al. 2011). Indeed, as mentioned by Eaton et al. (2004), this higher complexity might explain why only a small share of European firms export to a larger number of markets. In this sense, Helpman (2006) emphasizes the importance of finding a systematic relationship between the firms' characteristics and their participation in foreign trade and investment (p. 590). This fact is especially relevant for policymakers. As the firms' characteristics play a key role in their international activity both in terms of their volume of operations and concerning the number of markets they operate in, domestic economic policies aimed at stimulating the

\footnotetext{
${ }^{1}$ Here, "complexity" refers to the process of switching from domestic to exporter and from exporter to FDI, as in Chen and Moore (2010). In this sense, "complexity" should be distinguished from "complex FDI" (Yeaple 2003). We thank an anonymous referee for bringing this difference to our attention.

${ }^{2}$ Standard models of horizontal FDI do not discriminate production and distribution activities. However, recent works consider alternative ways of internationalization, such as export-platform FDI (Yeaple 2003) or export-supporting FDI (Krautheim 2013).
} 
internationalization strategies of firms should be focused on improving the general business environment in order to foster innovation, productivity, and growth of firms.

In this paper, we examine empirically how important the characteristics of European firms are in determining their cross-country structure of international activity. Specifically, we focus on the link between the differences in productivity and size (among other attributes) of firms and the number of foreign markets they serve either through exports or by a foreign affiliate.

The evidence in this respect, which focuses on a few case studies of different countries, confirms the predictions that only the more productive firms are able to operate in more than a few foreign markets. For instance, Eaton et al. (2004) for French firms, Bernard et al. (2005) for US firms or Lawless (2009) for Irish firms show empirically that most firms export to only a single market, and that the number of exporters dramatically decreases with the increase in the number of export destination markets. Similarly, according to Yeaple (2009) and Tanaka (2012), who analyze US and Japanese multinationals firms, respectively, only a few firms, the more productive ones, own affiliates in more than a handful of foreign markets.

Most of these empirical findings have been supported by theoretical developments, which in turn have mainly centered on a particular internationalization strategy: exports or FDI. Following Helpman et al.'s (2004) model, Yeaple (2009) and Chen and More (2010) examined how firm characteristics explain the cross-country structure of multinational enterprises (MNEs). They concluded that firms that are more productive invest in a larger number of markets. Likewise, using a static version of the Melitz (2003) model, Lawless (2009) suggested a similar hierarchy considering only exporting and non-exporting firms.

Based on this range of trade models, we present here a simple model where both internationalization strategies-exports and FDI - are explicitly feasible. Under this framework, outcomes in productivity thresholds show that a strict hierarchy of entry into foreign markets (as shown in previous models for exports or FDI) can only be established for firms carrying out FDI, but not for exporters. This result might indeed explain why Lawless (2009) was only able to find weak support of her prediction using the data. ${ }^{3}$

\footnotetext{
${ }^{3}$ The productivity cut-offs generated in her model predict a hierarchy of markets that firms would be expected to enter in an established order according to their productivity.
} 
Empirically, we contribute to the literature in several ways. First, we make use of a unique survey data of firms from seven European countries (in short, the EFIGE dataset). ${ }^{4}$ This survey contains homogeneous and consistent information on all the international activities for manufacturing firms, combined with detailed data on their characteristics, thus allowing us to fill a gap in the literature. Probably limited by the lack of homogenous datasets, the few cases that empirically analyze the influence of firms' characteristics on the number of markets they serve are country-specific and focus on a specific internationalization strategy (exports or FDI). The wide span of information that EFIGE provides allows us to test the previous theoretical conclusions for both exporters and investors from a set of European economies.

Second, in order to test the predictions of the model, we rely on two different econometric methodologies. Initially, we estimate a multinomial logit model (MNL) to evaluate to what extent firm heterogeneity influences the decision to extend exports or foreign production beyond a single foreign market. On the one hand, the results obtained using this methodology confirm the implications of the previous theoretical and empirical studies for the European case. In line with preceding works, our estimates show that European firms whose activity is restricted to the domestic market are less productive, smaller, younger, and less intensive in physical and human capital and in R\&D activities than firms that participate in international activities. Similarly, firms engaging in FDI show higher values of these characteristics than exporters. However, in this paper, we go a step further by demonstrating, on the other hand, that these firm characteristics exert a higher impact on the internationalization strategy decision for exporters and investors that operate in more than a single market. As an additional contribution, we confirm not only the higher fixed costs that operating abroad implies (relative to firms that are non-active abroad), but also the greater costs involved in serving more than one foreign market through exports or FDI. This indeed might explain why only a small share of European firms are active in a foreign country in a larger number of markets.

Next, we perform a quantile regression $(\mathrm{QR})$ for a count data model to analyze how changes in firms' characteristics affect their particular foreign market scope. Specifically,

\footnotetext{
4 The EU-EFIGE/Bruegel-UniCredit dataset is a database recently collected within the EFIGE project (European Firms in a Global Economy: internal policies for external competitiveness), supported by the Directorate General Research of the European Commission through its 7th Framework Programme and coordinated by Bruegel. See Altomonte and Aquilante (2012), for more information.
} 
this estimation method, used to our knowledge for the first time in the context of modeling firm heterogeneity, allows us to weight the effect that covariates exert on the exact number of foreign markets served at different degrees of internationalization. The results of this analysis suggest, firstly, the existence of heterogeneous effects and non-linearities in the relationship between firms' characteristics and the number of markets in which they operate. Secondly, consistent with the conclusions of the model, they show some important differences between exporters and firms engaging in FDI. We find that while for exporters productivity, capital intensity, human capital, and $R \& D$ have a positive effect on the number of markets served, for firms investing abroad only productivity, size and capital, and R\&D intensity are relevant factors in explaining their international market scope. Finally, and probably more important for us, we corroborate that in a framework where both internationalization strategies coexist (exports and FDI) it is possible to establish a hierarchy for firms investing abroad, but not for exporters. In the case of FDI firms, the estimates confirm that the above characteristics are positively related to the number of markets they operate in. However, for exporters, an improvement in these firm characteristics will imply operating in a higher number of markets only in the lowest quantiles.

The rest of the paper is organized as follows. In the next section, we present a model to analyze the relationship between firm heterogeneity and the increasing complexity of the internationalization strategy. Section 3 shows the data description and some stylized facts about European manufacturing firms with internationalization activities. Section 4 describes the econometric methodology. Section 5 presents the estimation results and the final section concludes.

\section{The model}

This paper builds on research by Helpman et al. (2004) and Yeaple (2009) as a basic framework to illustrate the relationship between firm heterogeneity and the market scope of firms' internationalization decisions. Following these models, we rely on CES preferences (with elasticity of substitution across goods equal to $\sigma>1$ ) and monopolistic competition. The representative consumer allocates her/his expenditure across different varieties of a representative industry in country $j$, in accordance with their subutility function subject to country $j$ 's total expenditure, $E_{j}$. Finally, each firm producing a variety 
of the differentiated good is endowed with a productivity (output per unit labor) $\theta$, drawn from a common distribution $G(\theta)$.

Given that firms are assumed to be atomistic, each firm treats the elasticity of substitution, $\sigma$, as its own price elasticity of demand, and the delivery price set by a representative firm producing in country $i$ and selling in $j$ is $p_{i j}=\frac{\sigma}{\sigma-1} \frac{\tau_{i j} w_{i}}{\theta}$, where $\frac{\tau_{i j} w_{i}}{\theta}$ is the marginal cost of serving country $j$ by a firm producing in country $i$. Hence, this last term depends on three factors: 1) the firm's productivity, $\theta ; 2$ ) the composite input cost required to produce the representative variety in country $i, w_{i}$; and 3 ) the transport costs of serving country $j$ from a firm located in country $i, \tau_{i j}$, where $\tau_{i j}$ is the iceberg transport cost factor, with $\tau_{i j}>1$ for all $i \neq j$, and $\tau_{i j}=1$ for all $i=j$.

Under these assumptions, if we denote as $Y_{j}$ the mark-up adjusted total expenditure in a representative industry, ${ }^{5}$ the gross profit earned in each destination market $j$ by a representative firm producing in country $i$ could be written as: $\pi_{i j}=Y_{j}\left(\frac{\tau_{i j} w_{i}}{\theta}\right)^{1-\sigma}$. However, as stated by Helpman et al. (2004), if firms have to incur in a fixed entry cost to serve each foreign market $j$, and the magnitude of this fixed cost differs if the market is served by exports $\left(f_{j}^{X}\right)$ or via FDI $\left(f_{j}^{I}\right)^{6}$, with $f_{j}^{I}>f_{j}^{X}$ for all $j$, the net profit earned in each destination market $j$ is, $\pi_{j}^{X}=Y_{j}\left(\frac{\tau_{h j} w_{h}}{\theta}\right)^{1-\sigma}-f_{j}^{X}$ for firms which choose to export, and $\pi_{j}^{I}=Y_{j}\left(\frac{w_{j}}{\theta}\right)^{1-\sigma}-f_{j}^{I}$ if a firm decides to open a new plant in country $j .^{7}$

Finally, we assume that transport costs are high enough compared with differences in wage costs between countries, thus avoiding the appearance of export platforms, as in Yeaple (2009). It is also assumed that the relative marginal cost of serving market $j$ from home through exports rather than through a foreign affiliate is relatively small, given the difference between the fixed costs of opening an affiliate in $j$ compared to the fixed cost

\footnotetext{
${ }^{5}$ Namely, $Y_{j}=\frac{E_{j}}{\sigma P_{j}}$ and $P_{j} \equiv \sum_{k=1}^{N} m_{k} p_{k j}^{1-\sigma}$, where $E_{j}$ is country $j$ 's total expenditure; $p_{i j}$ is the delivery price of a variety produced in $i$ and sold in $j ; m_{j}$ is the number of varieties produced in country $j$, and $N$ is the total number of markets considered.

${ }^{6}$ In this model, it is assumed that both internationalization strategies are substitute ways to enter in each foreign market.

${ }^{7}$ Remember that $\tau_{i j}=1$ for all $i=j$.
} 
of entering through exports (as in Helpman et al. 2004), that is, than $\frac{f_{j}^{I}}{f_{j}^{X}}>\left(\frac{w_{j}}{\tau_{h j} w_{h}}\right)^{1-\sigma}>$ 1.

As is well known, under these assumptions, both $\pi_{j}^{X}$ and $\pi_{j}^{I}$ are increasing functions with firm productivity, $\theta$, but $\pi_{j}^{I}$ increases faster than $\pi_{j}^{X}$. Accordingly, there exists a range of sufficiently high productivities for which the operating profits of serving a market through exports are positive and greater than the operating profits from serving it by FDI. Thus, taking into account the previous assumption and the operating profits obtained by a firm that decides to serve market $j$ through exports or through FDI, we have that there will be a pair of productivity cutoffs for each market $j, \theta_{j}^{X}$ and $\theta_{j}^{I}$. These are given by the following expressions,

$$
\theta_{j}^{X}=\theta\left(\pi_{j}^{X}=0\right)=\left[\frac{1}{\left(\tau_{h j} w_{h}\right)^{1-\sigma}}\left(\frac{f_{j}^{X}}{Y_{j}}\right)\right]^{\frac{1}{\sigma-1}}
$$

and,

$$
\theta_{j}^{I}=\theta\left(\pi_{j}^{X}=\pi_{j}^{I}\right)=\left[\frac{1}{w_{j}^{1-\sigma}-\left(\tau_{h j} w_{h}\right)^{1-\sigma}}\left(\frac{f_{j}^{I}-f_{j}^{X}}{Y_{j}}\right)\right]^{\frac{1}{\sigma-1}}
$$

Therefore, if a firm from country $h$, with productivity $\theta$, verifies $\theta_{j}^{X} \leq \theta<\theta_{j}^{I}$, this will serve market $j$ by export. Conversely, if $\theta \geq \theta_{j}^{I}$, the firm will become involved in FDI and serve market $j$ through a local affiliate. From (1) and (2) it is obvious that an increase in the size of the market, $Y_{j}$, reduces both cutoffs, thereby inducing the less productive firms to engage in international activities. However, a reduction in the fixed or labor cost of serving the foreign market by exports, as well as in the transport costs, will diminish the productivity cutoff of exporting, thus inducing the less productive firms to export to $j$. An increase in these variables, as well as a reduction in the fixed or variable labor costs of serving the foreign market by opening an affiliate, will reduce the productivity cutoff necessary to enter $j$ via FDI, thus encouraging the firm to open an affiliate in country $j$. 
In this kind of models, the productivity cutoffs of markets allows us to identify the mechanisms through which country characteristics affect the structure of firms' international activity, but also set up the relationship among firms' productivity and the scope of their international activity. Obviously, as stated by Melitz and Redding (2014), in this type of model, productivity "is a catch-all that includes all sources of heterogeneity in revenue relative to factor inputs across firms, including differences in technical efficiency, management practice, firm organization, and product quality". 8 These characteristics determine whether a firm decides to serve each foreign market or not, how to do it (by exporting or through a local affiliate), and the range of markets in which they are active.

Eq. (2) provides a well-known result, according to which we can rank all markets from the highest to the least attractive (in accordance with their productivity cutoffs), thereby establishing a hierarchy of different markets, as in Yeaple (2009). Hence, if a firm serves a market through an affiliate, it will do the same in all other markets that are more attractive in the hierarchy. Therefore, the most productive firms will invest in a larger number of markets (because their productivity exceeds the productivity cutoff for a larger number of countries). Similarly, Lawless (2009), in a model based on Melitz (2003), without the possibility of serving foreign markets by mean of an affiliate (that is, focusing only on Eq. (1)), showed that it is also possible to establish a similar hierarchy for exporters, the conclusion being that more productive firms will serve a larger number of markets by exports.

However, in the model we have just outlined, more productive exporters will not necessarily export to more destination markets. The reason for this is that, given the characteristics of potential destination markets, as a firm's productivity increases, a shift in the way of serving foreign markets may occur, changing from exports to FDI, thus breaking the hierarchy in the case of exports. We illustrate this possibility in the next example (see Figure 1).

\footnotetext{
${ }^{8}$ Melitz and Redding (2014), p.8.
} 
Figure 1: Firms' productivity and market cutoffs.

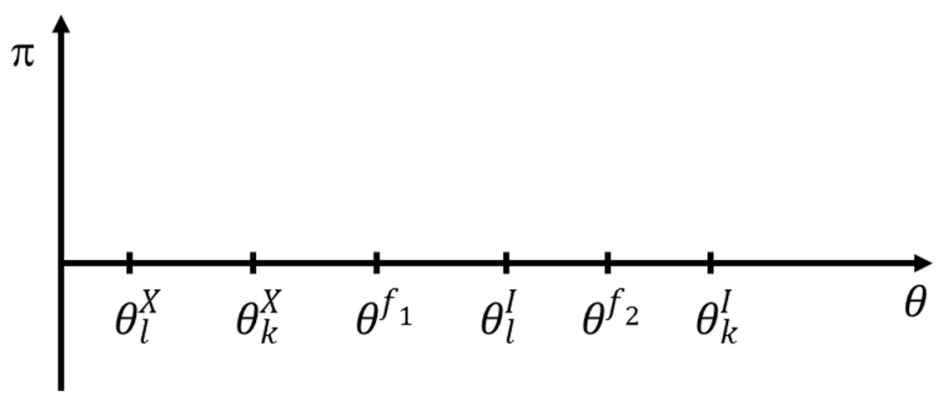

Consider, for instance, two markets, $l$ and $k$, such that $\theta_{l}^{X}<\theta_{k}^{X}$ and $\theta_{l}^{I}<\theta_{k}^{I}$. Let us assume that, given the market characteristics, the respective productivity cutoffs of exporting or investing in each of them can be arranged as follows: $\theta_{l}^{X}<\theta_{k}^{X}<\theta_{l}^{I}<\theta_{k}^{I}$. Now, let us take two firms with productivities $\theta^{f_{1}}$ and $\theta^{f_{2}}$, such that $\theta^{f_{1}}<\theta^{f_{2}}$ and $\theta_{l}^{X}<\theta_{k}^{X}<\theta^{f_{1}}<$ $\theta_{l}^{I}<\theta^{f_{2}}<\theta_{k}^{I}$. Then, the firm endowed with productivity $\theta^{f_{1}}$ serves the two markets $(l$ and $k$ ) by exports, but the firm with productivity $\theta^{f_{2}}>\theta^{f_{1}}$ will export only to one market $(k)$.

In short, we can say that while other models have emphasized the possibility of establishing a clear hierarchy between the number of international markets to be attended and firms' characteristics, this relationship is only robust when both ways of internationalizing (exports and FDI) are separately considered and under certain restrictive scenarios. When both internationalization strategies are considered simultaneously as alternative ways to serve foreign markets, this strict hierarchy disappears in the case of exports, holding only for investors. This is precisely what our paper tries to prove empirically for the case of European firms in the next sections.

\section{Data description and stylized facts: The case of EU multinational firms}

This paper is based on firm-level data from the EU-EFIGE/Bruegel-UniCredit dataset (EFIGE). This database is unique in that it provides homogenous information from a representative sample of almost 15,000 surveyed manufacturing firms involved in international activities from seven European economies: Germany, France, Italy, Spain, United Kingdom, Austria, and Hungary. As previously mentioned, the lack of statistical information has so far prevented the inclusion of firm-level characteristics in the 
empirical studies of firms' internationalization activities that consider more than one country of origin. ${ }^{9}$

In this dataset, the destination markets for firms involved in international activities through exports or foreign direct investment are grouped in the following areas: (i) 15EU, (ii) other EU countries, (iii) other European countries not EU, (iv) China and India, (v) other Asian countries (excluding China and India), (vi) USA and Canada, (vii) Central and South America, and (viii) other areas. The survey data with a cross-section format was collected in 2010 covering the period from 2007 to 2009.

\section{INSERT TABLE 1 HERE}

In Table 1, we present a detailed description of the data employed for our empirical analysis. In order to capture the possible changes in the total factor productivity (TFP) of firms over time, two different measures of TFP have been used: the average TFP for the period 2001-07, and the TFP for the period 2008-09. Following previous literature, we also include total employment as a measure of firms' size, and the capital labor ratio to proxy capital intensity. In order to go deeper into the connections between firm heterogeneity and its internationalization decisions, we further consider other firm attributes, such as human capital, R\&D intensities, the years of establishment (age), and the role of the firms' organizational structure (centralized decision-making). ${ }^{10}$

\section{INSERT TABLE 2 HERE}

In Table 2, we provide the average values of these firm characteristics for each strategy. Specifically, we have divided the sample into three categories: domestic, exporter, and FDI. The first category includes only firms that are non-active abroad, while the second and third categories include exporters from the home country and firms engaging in FDI, respectively. Several facts can be derived from this information. Firstly, as can be appreciated, $74 \%$ of the firms in our sample are active internationally, indicating that the vast majority of firms choose to expand internationally. ${ }^{11}$ Secondly, most of the firms that

\footnotetext{
${ }^{9}$ The few empirical studies on this issue focus on one single economy (see, for instance, Eaton et al. 2004; and Lawless 2009, for exporters, and Yeaple 2009, Chen and Moore 2010, and Tanaka 2012, for FDI). ${ }^{10}$ According to some studies (see e.g., Bartlett and Ghoshal 2002, Sander and Carpenter 1998, or Hsu et al. 2013), firms require a higher delegation of authority and responsibility (decentralization) when the degree of firms' internationalization increases.

${ }^{11}$ As mentioned in the EU-EFIGE/Bruegel-UniCredit dataset (Altomonte and Aquilante 2012) report, the fact that the internationally active firms are more numerous in the sample with respect to the domestic firms
} 
expand abroad actively (93\%) are exclusively exporters, while the rest (7\%) are firms that engage in FDI projects. This probably reflects the different entry costs associated to each internationalization strategy and, particularly, the higher fixed investment costs involved in setting up a production plant abroad. These figures also reveal that, on average, firms that are non-active abroad are less productive, smaller, younger, and less intensive in physical and human capital, and R\&D than those firms that participate in international activities. Furthermore, in line with previous studies, firms engaging in FDI show higher values of the above-mentioned characteristics than exporters (see e.g., Helpman et al. 2004; Tomiura 2007; Martí et al. 2015).

Figure 2. Number of destination markets for exporters and firms engaging in FDI.

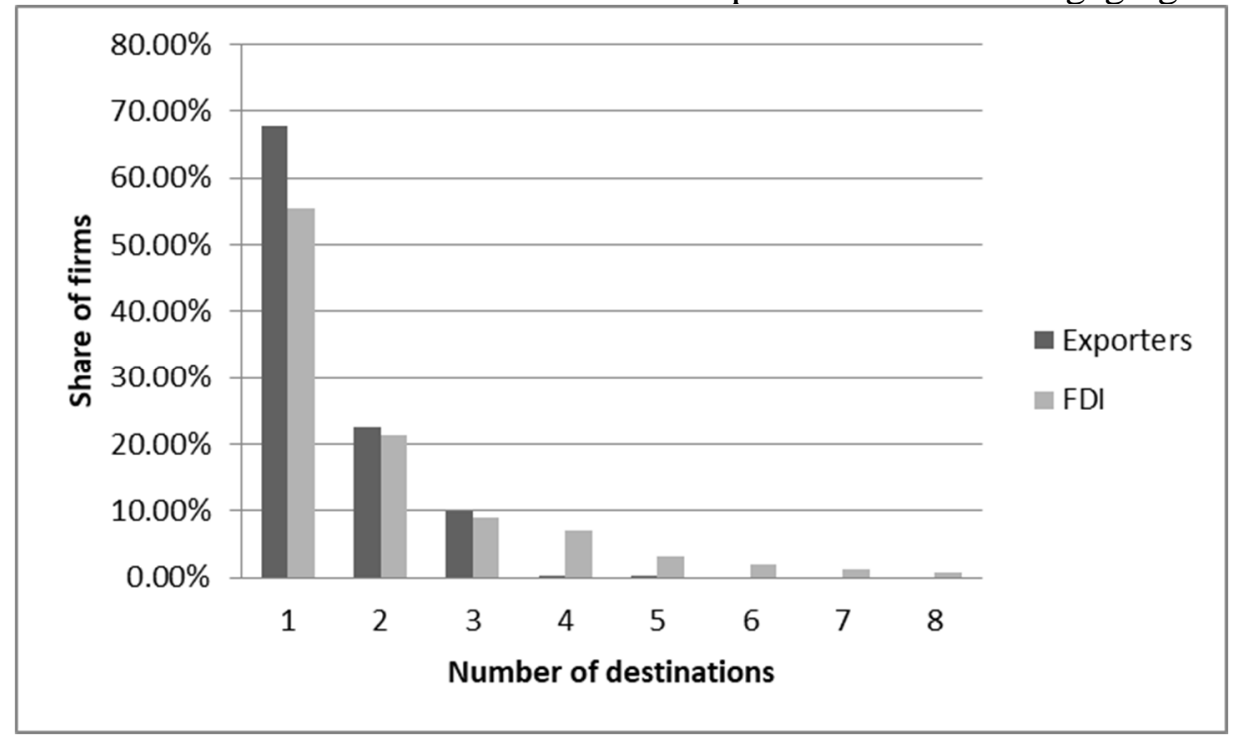

Source: Authors' calculations from EU-EFIGE/Bruegel-UniCredit dataset.

Last but not least, in Figure 2, we show how the share of both exporters and firms that engage in FDI activities decreases dramatically with the increase in the number of destination markets. As pointed out by Barba-Navaretti et al. (2011), this could be due to the increase in the complexity of the internationalization strategies involved in serving a greater number of markets. According to these authors, attending a larger number of markets will imply to assume the extra costs of serving each new destination.

\section{Estimation methodology}

With the purpose of obtaining a broad empirical view of the relationship between firms' characteristics and the scope of their international activity, here we employ two

derives from the truncation of the sample, which considers a representative sample of manufacturing firms with a lower threshold of 10 employees. 
econometric methodologies: A multinomial logit model (MNL), and a quantile regression (QR). On the one hand, the MNL model provides us with an adequate framework to estimate how divergences in firms' characteristics influence their internationalization strategy and, more specifically, to what extent they affect, on average, the decision to serve more than one single market via exports or FDI. On the other hand, as a complementary analysis, the QR regression makes it possible to evaluate the effects of firm characteristics on the actual number of foreign markets attended by firms at different points of the probability distribution. ${ }^{12}$

The MNL model, like other common regression methods, assumes that the relationship between the outcome of interest and the covariates remains the same across different values of the endogenous variable. However, it is also relevant to know whether firms serving a higher number of foreign markets behave differently from those with a small foreign market scope. QR allows us to test this fact.

\subsection{Multinomial logit model}

As is well known, the MNL model provides an adequate framework with which to analyze firms' decisions when the choice among alternatives is modeled as a function of the firm's characteristics (rather than characteristics of the alternatives). In particular, based on a random profit maximization framework, the MNL assumes that each investor that faces a finite set of mutually exclusive strategies, $s \in\left\{h, x_{1}, x_{N}, i_{1}, i_{N}\right\}$, selects the strategy that yields the highest profit. In our case, $s$ represents the strategies of: domestically oriented firms $(h)$, exporting to a single market $\left(x_{1}\right)$, exporting to multiple markets $\left(x_{N}\right)$, investing in a single market $\left(i_{1}\right)$, or investing in multiple markets $\left(i_{N}\right)$.

According to the MNL model, the expected profit of a firm from each strategy consists of two components, the deterministic part, which depends on a strategy-specific parameter, $\alpha_{s}$, on a set of observed firm characteristics, $X$, and the unobservable part, which is captured by a stochastic term, $\varepsilon$. That is:

$$
\pi_{s}=\alpha_{s}+\beta_{s} X+\varepsilon_{s}
$$

\footnotetext{
${ }^{12}$ For economic applications of quantile regression, see Fitzenberger et al. (2013).
} 
Given that $\varepsilon$ is unknown, the firms' final strategy is predicted in terms of probability. More specifically, the probability that a firm selects one strategy $s$ rather than another (denoted as $k$ ) can be defined as:

$$
P r_{s}=P\left(\pi_{s}>\pi_{k}\right)
$$

To solve the above equation, we should impose a probability density function on $\varepsilon_{s}$. In particular, if we assume that the error term is independently and identically distributed with type I extreme value distribution, ${ }^{13}$ the probability of a firm choosing strategy $s$ is given by:

$$
P r_{s}=\frac{\exp \left[\alpha_{s}+\beta_{s} X\right]}{\sum_{k=1}^{K} \exp \left[\alpha_{k}+\beta_{k} X\right]}
$$

Since $\sum_{k} P r_{k}=1$, the $K$ sets of parameters $(\alpha, \beta)$ are not unique. So, to identify the parameters $\alpha_{s}$ and $\beta_{s}$, we need to fix the coefficients for one strategy to zero: in this case the strategy of serving the home market domestically (that is, $\alpha_{h}=0$ and $\beta_{h}=0$ ). Thus, the remaining coefficients would measure the relative change with respect to the base group or strategy. In fitting such a model, the estimated MNL model becomes:

$$
\operatorname{Pr}_{s}=\frac{\exp \left[\alpha_{s}+\widetilde{\beta}_{s} X\right]}{1+\sum_{k=1}^{K} \exp \left[\alpha_{k}+\beta_{k} X\right]}
$$

where the coefficients $\beta_{k}=\left(\beta_{k}-\beta_{h}\right)$ now represent the effect of the $X$ variables on the probability of choosing the $k^{\text {th }}$ strategy over the alternative to locate in the home country and serve it domestically. In the above equation, the constant term $\alpha_{k}=\left(\alpha_{k}-\alpha_{h}\right)$ depicts specific physical costs and informational barriers for each strategy that are invariant across firms (Aw and Lee 2008).

\subsection{Quantile regression}

By using the conditional quantiles, $Q_{y}(q \mid X), \mathrm{QR}$ allows us to consider the impact of a regressor on the entire distribution of our dependent variable (and not only on its

\footnotetext{
13 The iid assumption on the error term imposes the property of independence of irrelevant alternatives (IIA). According to this property, the ratio of probabilities of choosing between two strategies depends only on the attributes of these two strategies, and is independent of the attributes of other possible alternatives.
} 
conditional mean). This ability to provide a comprehensive description of the distributional effects has contributed to make QR popular in several research fields. ${ }^{14}$ However, in the specific research field about the links between firm heterogeneity and the scope of internationalization activities, applications are yet to come. Previous results have generally been reached by using standard ordinary least squares estimations (Chen and Moore 2010), which contribute to explain the effects on the conditional mean value of the variable of interest, but not how the impact that a covariate has on this variable may vary at different quantiles. QR provides, however, a complete view of the effects of the predictors, $X$ (firm characteristics), on the entire distribution of our response variable, $y$ (number of foreign markets served in each internationalization strategy).

In the standard QR model, the parameter coefficients are estimated by minimizing the $100 q$ th quantile of the conditional distribution of $y$. So, the $100 q$ th of $y$ given $X$ is defined as $Q_{y}(q \mid X)=\min \left[\sum_{i: y_{i} \geq Q_{y}(q)} q\left|y_{i}-Q_{y}(q \mid X)\right|+\sum_{i: y_{i}<Q_{y}(q)}(1-q)\left|y_{i}-Q_{y}(q \mid X)\right|\right] .{ }^{15}$ Yet, for a count data model, the objective function, $y$, is not differentiable, thus making it difficult to express the quantiles directly as a continuous function of predictor variables. In this context, an estimation of the conditional quantiles using standard econometric tools is therefore not possible (see Miranda, 2008, for a more detailed explanation of this fact). It is precisely this complication that has made QR for counts unavailable until very recently.

To overcome these limitations, Machado and Santos Silva (2005) propose to build a continuous random variable whose quantiles have a one-to-one relationship with the quantiles of the count, $y$. This can be achieved by constructing an auxiliary variable, $z_{i}=$ $y_{i}+u_{i}$, where $u$ is a uniformly distributed random variable, such that the standard QR can be applied to a monotonic transformation of $z$. To remove the noise artificially created in the smoothing process, following Machado and Santos Silva's (2005) recommendations, Miranda (2007) suggests calculating the average of the QR estimates of $m$ jittered samples. In this work, we use the method developed by this author to estimate the QR regarding how firms' characteristics affect the number of markets served. ${ }^{16}$

\footnotetext{
${ }^{14}$ See Yu et al. (2003) and Koenker (2005) for an overview of recent applications of this methodology.

${ }^{15}$ Koenker and Basett (1978).

${ }^{16}$ Machado and Silva's jittering algorithm was implemented in statistical software by Miranda (2007).
} 


\section{Main results}

In order to enter any foreign market, firms must be sufficiently efficient to be able to cover the additional costs of such activity, and this efficiency must increase with the number of markets where they are operative. In this section, we examine this relationship between firm characteristics and the market scope of their international activity, both for exporters and for multinational companies.

\subsection{Firm heterogeneity and the complexity of firm internationalization}

In Table 3, we show the results of the MNL model by considering as explanatory variables firms' TFP jointly with other firm-specific characteristics that may influence efficiency and thus the extent of market coverage strategy. Additionally, in Table 4, we present the estimates of these regressions when the size and the capital intensity of firms are included instead of productivity. The theoretical relationship between the size of the firms (output/labor ratio), the capital-labor ratio, and productivity prevents us from using them simultaneously. As can be seen in Helpman et al. (2004), under certain assumptions about the distribution function of the TFP, the distribution of size is based on the same parameters. Similarly, given the relationship between capital-labor and TFP from the production function, this ratio has often been used to proxy productivity (see, for instance, Tomiura 2007). Results from the basic models, with only TFP or, alternatively, with size and capital intensity as discriminatory firm characteristics, are shown in the Appendix (Table A.1).

\section{INSERT TABLE 3 HERE}

\section{INSERT TABLE 4 HERE}

In these tables, the coefficients of each variable in the first four columns describe the influence of the different covariates on the likelihood of a firm belonging to the different internalization strategies (exporting to a single market, exporting to multiple markets, investing in a single foreign market, or investing in multiple markets) relative to the base strategy of firms that are non-active abroad. Conversely, the following two columns report the differences in the coefficients when the internationalization strategy, exports or FDI, takes place in multiple destinations instead of in a single market. Differences in 
the coefficient across other internationalization strategies are reported in the last four columns.

Several outcomes are derived from the estimates above. Firstly, the negative and significant effects of constant terms are reflecting the higher fixed costs involved in operating actively abroad relative to firms that are non-active abroad, conditional to all the firm characteristics, as pointed out by Aw and Lee (2008). Secondly, and in line with previous studies (see, for instance, Helpman et al. 2004, and Tomiura 2007, for American and Japanese firms, respectively), the outcomes confirm that firms involved internationally are more productive, larger, older, and more capital and R\&D intensive than firms that are non-active abroad. Moreover, it is found that the variable related to centralized decision-making is negative and significant, thereby indicating that firms with international activity have more decentralized structures than those that operate only in the domestic market. This agrees with some studies on internationalized firms in the management literature, which point out that when the degree of internationalization strategy increases, the parent firms find it more useful to delegate more decisions, particularly to their foreign affiliates (Bartlett and Ghoshal 2002; Sanders and Carpenter 1998; and Hsu et al. 2013).

But our results, as depicted in the fifth and sixth columns, go a step further by showing that these firm characteristics exert a higher impact on the internationalization strategy decision for exporters and investors which operate in more than a single market. We found that the most productive firms engage in FDI and have affiliates in multiple markets, but that the largest, oldest, and the most decentralized, and capital and R\&D intensive firms also do the same. We obtain similar conclusions for exporters, thus corroborating that only those exporters with the highest values of early firm characteristics (except for the centralized decision-making variable) are able to export in more than a single market. Note, however, that the results regarding human capital reveal that there are no significant differences between investing firms operating in a single market or in several markets. For exporters, this variable plays a greater role for those that focus on one single destination. Additionally, the outcomes confirm that firms involved in a larger number of foreign markets through exports or opening foreign affiliates assume higher fixed costs than their respective peers involved in a single market. Finally, as depicted in the last four columns, we observe that, regardless of the market scope, firms that invest abroad to serve a foreign destination are more productive, human capital and R\&D intensive, and older 
than exporters. Similar results are found in general when we include the number of workers and capital-labor ratio instead of productivity.

\subsection{Relationship between firm characteristics and the number of markets served}

A more detailed analysis of the relationship between firms' characteristics and the number of markets to be served is carried out by estimating a QR model. ${ }^{17}$ Specifically, in this section, we perform the QR of the extended model for both exporters and firms engaging in FDI (see Tables 5, 6 and 7). Results for the main quantiles for the different internationalization strategies are presented in the first four columns, while the last column reports the estimation to median regression (quantile 0.5). ${ }^{18}$

\section{INSERT TABLE 5 HERE}

\section{INSERT TABLE 6 HERE}

\section{INSERT TABLE 7 HERE}

The outcomes from the tables above show some significant relationships between the different firm characteristics and their participation in a larger number of markets, for both exporters and firms investing abroad. The coefficients on the different covariates have similar signs in all quantiles and the mean, indicating that the effects of these variables, although they may be different in magnitude and significance, are consistent in terms of direction. For exporters, productivity, human capital, and R\&D and capital intensity exhibit a positive relationship with the number of markets to be served, while a negative effect of centralized decision-making is obtained for a higher geographical scope of internationalization. This confirms that, as we derived from the MNL estimates, firms exporting to a larger number of markets are more decentralized. Moreover, as shown in Tables 6 and 7, these results do not rely on the variable used to measure TFP. From these tables, we can conclude that size and capital intensity also have a positive influence on the number of markets to be attended.

\footnotetext{
${ }^{17}$ Few studies have analyzed this relationship, in the vast majority of cases yielding only descriptive statistics (Yeaple 2009; Navaretti et al. 2010), or using OLS estimations, and just for FDI firms, focusing on productivity as the only source of firm heterogeneity (Chen and Moore 2010). These works have provided useful insights about a positive relationship between firm productivity and the number of markets served, as commented on throughout this paper.

${ }^{18}$ See Tables A.2, A.3 and A.4 in the Appendix to observe results from the basic models.
} 
For investing firms, we obtain similar results except for human capital (HK). In this case, HK is not significant in the explanation of the scope of foreign investments when TFP is included. This is in line with our previous results, which showed that this variable was not relevant in the decision to undertake foreign investment in some of the scenarios considered (see Tables 3 and 4).

Yet the above-mentioned effects, although equal in terms of direction, differ in magnitude and significance at different quantiles, thus suggesting the existence of heterogeneous effects and non-linearities. For firms investing abroad, we observe that the coefficients on productivity, size, and capital and $R \& D$ intensities increase progressively from the lowest quantiles to the highest ones. ${ }^{19}$ This finding suggests that the impact of the different firm characteristics on the number of foreign markets served will increase for firms engaging in FDI in a larger number of markets. That is, for firms doing FDI, the efficiency increase required to attend an additional market is higher for firms investing in a smaller number of markets than for firms operating in a larger number of destinations.

However, in line with our predictions, results are rather different when we look at exporters. In this case, our estimates show that the positive relationship between firms' characteristics and the number of markets they export increases only along the lowest quantiles. The marginal benefits (in terms of numbers of markets to be attended) from increasing the firm's productivity, physical and human capital, and R\&D intensities rapidly decrease after quantile 0.4 . The firms' productivity variables even have a nonsignificant effect in the highest quantiles. This supports the idea that a firm with a higher level of productivity will invest in a greater number of markets, but will not necessarily export to a higher number of markets. As shown in our model, it might be a productivity cutoff beyond which firms may change their internationalization strategy from exporting to serving a foreign market through an affiliate. This would indeed justify the different outcome for exporters than for foreign investors. These results are also consistent with the weak evidence found by Lawless (2009) in sequencing export markets for Irish firms, or by Eaton et al. (2011), who found substantial deviations from a predicted market hierarchy for French exporter firms.

\footnotetext{
${ }^{19}$ Recall that the quantile regression parameter estimates the change in a specified quantile of the response variable produced by one unit change in the predictor variable.
} 


\section{Conclusions}

Recent literature on firm heterogeneity has shown that firms' characteristics play a key role in determining their internationalization decisions. This study tries to bring more light to this literature by analyzing the relationship between the heterogeneity of European firms and the number of markets served through both exports and FDI.

Based on the models put forward by Helpman et al. (2004) and Yeaple (2009), we show, theoretically, that in a framework where both internationalization strategies coexist, i.e., exports and FDI, a strict hierarchy of entry into foreign markets can only be established for firms that open foreign affiliates by engaging in FDI, but not for exporters. Empirically, we have verified this outcome for the European case. We have used a rich dataset that combines information on European firms' characteristics and their internationalization activities with the number of markets served. In the econometric analysis, we have employed two different methodologies: multinomial logit and quantile regression models.

Our results from the multinomial logit model confirm the evidence provided by some previous studies showing that firms that are non-active abroad are less productive, smaller, younger, and less capital, R\&D and human capital intensive than firms that are active abroad. They also show that European firms engaging in FDI display higher values for the previous firms' characteristics than exporters. In this study, we have further included a variable related to centralized decision-making, the results showing a significant relationship between the degrees of complexity of internationalized firms and their internal performance. Moreover, we find that the increasing complexity of internationalization decisions, in terms of number of destinations, is associated with firm heterogeneity. Particularly, it is shown that firms operating in multiple markets through exports or FDI are more productive, larger, older, and more capital, R\&D and human capital intensive than those firms operating in a single market. Investing firms are also more decentralized. In sum, firm heterogeneity, regarding efficiency gains, is relevant to the internationalization strategy of European firms in terms of both the mode of entry into foreign markets — exporting or opening a local affiliate — and in terms of the number of foreign markets in which they are operative, that is, their market scope. Accordingly, domestic economic policies aimed at stimulating internationalization strategies of firms 
should resort more to measures designed to improve the overall business environment rather than to direct stimulus of firms.

The outcomes from the quantile regression ratify the significant relationship between productivity, size, capital and R\&D intensities, and the market scope of internationalized firms. Additionally, these estimates show that the influence of firm's characteristics on the number of markets served depends on how multinational it is, thereby suggesting that the relationship between the number of markets served and the firm's characteristics is heterogeneous and subject to non-linearities. Besides, a different behavior is observed for exporters and foreign investors. Specifically, we find that, for firms investing abroad, the firm characteristics outlined above increase progressively from the lowest quantiles to the highest ones. Nevertheless, when we consider only exporters, we obtain that the previous firm characteristics are increasingly associated with the number of markets only for the lowest quantiles.

In line with the theoretical framework, the result described above suggests that once an exporter reaches a certain level of performance in terms of productivity, $R \& D$ and human capital intensities, it may change from exporting to FDI in order to serve the foreign markets. This would prevent us from obtaining a clear hierarchy for exporting firms when FDI is also considered in the game. 


\section{References}

Altomonte, C., Aquilante, T., 2012. The EU-EFIGE/Bruegel-unicredit dataset (No. 2012/13). Bruegel working paper.

Aw, B.Y., Lee, Y., 2008. Firm heterogeneity and location choice of Taiwanese multinationals. Journal of International Economics, 75(1), 167-179.

Barba-Navaretti, G., Bugamelli, M., Schivardi, F., Altomonte, C., Horgos, D., Maggioni, D., 2011. The global operations of European firms-The second EFIGE policy report. Bruegel.

Bartlett, C. A., Ghoshal, S., 2002. Managing across borders: The transnational solution. Harvard Business Press.

Bernard, A., Jensen, J.B., 1999. Exceptional exporter performance: cause, effect, or both? Journal of International Economics, 47(1), 1-25.

Bernard, A.B., J.B. Jensen, P. K. Schott, 2005. Importers, Exporters and Multinationals: A Portrait of Firms in the U.S. that Trade Goods, NBER Working Paper No.11404.

Chen, M.X., Moore, M.O., 2010. Location decision of heterogeneous multinational firms. Journal of International Economics, 80(2), 188-199.

Eaton, J., Kortum, S., Kramarz, F., 2004. Dissecting trade: Firms, industries, and export destinations. American economic Review, 94(2), 150-154.

Eaton, J., Kortum, S., Kramarz, F., 2011. An anatomy of international trade: Evidence from French firms. Econometrica, 79(5), 1453-1498.

Fitzenberger, B., Koenker, R., Machado, J. A. (Eds.). 2013. Economic applications of quantile regression. Springer Science \& Business Media.

Girma, S., Kneller, R., Pisu, M., 2005. Exports versus FDI: an empirical test. Review of World Economics, 141(2), 193-218.

Head, K.,Ries, J., 2003. Heterogeneity and the FDI versus export decision of Japanese manufacturers. Journal of the Japanese and international economies, 17(4), 448-467.

Helpman, E., Melitz, M. J., Yeaple, S.R., 2004. Export versus FDI with heterogeneous firms. American Economic Review, 94(1), 300-316.

Helpman, E., 2006. Trade, FDI and the Organization of Firms. Journal of Economic Literature, 44, 589-630. 
Hsu, W. T., Chen, H. L., Cheng, C. Y., 2013. Internationalization and firm performance of SMEs: The moderating effects of CEO attributes. Journal of World Business, 48(1), $1-12$.

Koenker, R., Basett, G., 1978. Regression Quantiles. Econometrica, 46, 33-50.

Koenker, R., 2005. Quantile Regression. Cambridge University Press, New York.

Krautheim, S., 2013. Export-supporting FDI. Canadian Journal of Economics/Revue canadienne d'économique, 46(4), 1571-1605.

Lawless, M., 2009. Firm export dynamics and the geography of trade. Journal of International Economics, 77(2), 245-254.

Machado, J. A. F., Santos Silva, J. S., 2005. Quantiles for counts. Journal of the American Statistical Association, 100(472), 1226-1237.

Martí, J., Alguacil, M., Orts, V. (2015) Firm Heterogeneity and Location Choice of European Multinationals, MPRA paper 62596. http://mpra.ub.unimuenchen.de/62596/

Melitz, M.J., 2003. The impact of trade on intra-industry reallocations and aggregate industry productivity. Econometrica, 71(6), 1695-1725.

Melitz, M. J., Redding, S. J., 2014. Missing gains from trade?. The American Economic Review, 104(5), 317-321.

Miranda, A., 2007. QCOUNT: Stata Program to Fit Quantile Regression Models for Count Data. http://ideas.repec.org/c/boc/bocode/s456714.html

Miranda, A. 2008. Planned fertility and family background: a quantile regression for counts analysis. Journal of Population Economics, 21(1), 67-81.

Sanders, W. G., Carpenter, M. A., 1998. Internationalization and firm governance: The roles of CEO compensation, top team composition, and board structure. Academy of Management journal, 41(2), 158-178.

Tanaka, A. 2012. Firm productivity and the number of FDI destinations: Evidence from a non-parametric test. Economics Letters, 117(1), 1-3.

Tomiura, E., 2007. Foreign outsourcing, exporting, and FDI: A productivity comparison at the firm level. Journal of International Economics, 72(1), 113-127.

Yeaple, S.R., 2003. The complex integration strategies of multinationals and cross country dependencies in the structure of foreign direct investment, Journal of International Economics, 60 (2), 293-314. 
Yeaple, S.R., 2009. Firm heterogeneity and the structure of US multinational activity. Journal of International Economics, 78(2), 206-215.

Yu, K., Lu, Z., Stander, J., 2003. Quantile regression: applications and current research areas. Journal of the Royal Statistical Society: Series D (The Statistician), 52(3), 331350. 


\section{APPENDIX}

Table A.1. Multinomial logit regression of firm strategy decisions (TFP). Basic model.

\begin{tabular}{|c|c|c|c|c|c|c|c|c|c|c|}
\hline $\begin{array}{l}\text { Independent } \\
\text { Variables }\end{array}$ & Exporter single & Exporter multi. & FDI single & FDI multi. & $\begin{array}{l}\text { Exporter single } \\
\text { vs } \\
\text { Exporter multi. }\end{array}$ & $\begin{array}{l}\text { Exporter single } \\
\text { vs } \\
\text { FDI single }\end{array}$ & $\begin{array}{l}\text { Exporter single } \\
\text { vs } \\
\text { FDI multi. }\end{array}$ & $\begin{array}{l}\text { Exporter multi } \\
\text { vs } \\
\text { FDI single }\end{array}$ & $\begin{array}{l}\text { Exporter multi. } \\
\text { vs } \\
\text { FDI multi. }\end{array}$ & $\begin{array}{l}\text { FDI single } \\
\text { vs } \\
\text { FDI multi. }\end{array}$ \\
\hline Constant & $0.70(0.04) * * *$ & $-0.23(0.06)^{* * * *}$ & $-2.61(0.15) * * *$ & $-3.19(0.19)^{* * * *}$ & $0.93(0.05)^{* * * *}$ & $3.31(0.16) * * *$ & $3.89(0.19)^{* * *}$ & $2.37(0.15)^{* * * *}$ & $2.95(0.20)^{* * * *}$ & $0.57(0.24)^{* * *}$ \\
\hline TFP $(01 / 07)$ & $0.62(0.06) * * *$ & $0.94(0.08)^{* * * *}$ & $1.56(0.13)^{* * *}$ & $2.11(0.14)^{* * * *}$ & $-0.32(0.06) * * *$ & $-0.94(0.12)^{* * * *}$ & $-1.49(0.13)^{* * *}$ & $-0.61(0.12)^{* * *}$ & $-1.16(0.13)^{* * *}$ & $-0.55(0.16)^{* * *}$ \\
\hline $\begin{array}{l}\text { Industry fixed } \\
\text { effects }\end{array}$ & yes & Yes & yes & yes & yes & yes & yes & yes & yes & yes \\
\hline $\begin{array}{l}\text { Observations } \\
\text { Sample } \\
\text { Likelihood }\end{array}$ & $\begin{array}{l}5305 \\
10248 \\
-11728.97\end{array}$ & 2312 & 288 & 244 & & & & & & \\
\hline Constant & $0.73(0.05) * * *$ & $-0.23(0.06) * * *$ & $-2.53(0.16)^{* * *}$ & $-3.03(0.20)^{* * *}$ & $0.97(0.05)^{* * *}$ & $3.27(0.16) * * *$ & $3.77(0.20)^{* * *}$ & $2.98(0.16)^{* * *}$ & $2.79(0.21)^{* * * *}$ & $0.49(0.25)^{* * * *}$ \\
\hline TFP $(08 / 09)$ & $0.40(0.05) * * *$ & $0.57(0.06)^{* * * *}$ & $1.05(0.14)^{* * *}$ & $1.39(0.12)^{* * *}$ & $-0.17(0.05)^{* * *}$ & $-0.65(0.13)^{* * * *}$ & $-0.98(0.11)^{* * *}$ & $-0.48(0.13)^{* * *}$ & $-0.81(0.12)^{* * *}$ & $-0.33(0.16)^{* *}$ \\
\hline $\begin{array}{l}\text { Industry fixed } \\
\text { effects }\end{array}$ & yes & Yes & yes & yes & yes & yes & yes & yes & yes & yes \\
\hline Observations & 4778 & 2011 & 247 & 206 & & & & & & \\
\hline $\begin{array}{l}\text { Sample } \\
\text { Likelihood }\end{array}$ & $\begin{array}{l}9125 \\
-10432.97\end{array}$ & & & & & & & & & \\
\hline Constant & $-3.06(0.22) * * *$ & $-6.12(0.27)^{* * * *}$ & $-10.99(0.58)^{* * * *}$ & $-13.56(0.59)^{* * * *}$ & $3.05(0.19) * * *$ & $7.93(0.53) * * *$ & $10.49(0.56)^{* * * *}$ & $4.87(0.52) * * *$ & $7.43(0.55) * * *$ & $2.56(0.71)^{* * * *}$ \\
\hline Size & $0.57(0.04)^{* * * *}$ & $0.74(0.04)^{* * *}$ & $1.46(0.07)^{* * *}$ & $1.66(0.07)^{* * *}$ & $-0.17(0.02) * * *$ & $-0.89(0.05)^{* * *}$ & $-1.09(0.07)^{* * *}$ & $-0.71(0.06)^{* * *}$ & $-0.91(0.07)^{* * *}$ & $-0.20(0.08)^{* *}$ \\
\hline $\mathrm{K} / \mathrm{L}$ & $0.41(0.03) * * *$ & $0.72(0.04)^{* * *}$ & $0.64(0.10)^{* * *}$ & $0.85(0.08) * * *$ & $-0.30(0.03) * * *$ & $-0.23(0.09)^{* *}$ & $-0.44(0.07)^{* * *}$ & $0.07(0.09)$ & $-0.13(0.07)^{*}$ & $-0.21(0.11)^{*}$ \\
\hline $\begin{array}{l}\text { Industry fixed } \\
\text { effects }\end{array}$ & yes & Yes & yes & yes & yes & yes & yes & yes & yes & yes \\
\hline Observations & 4227 & 1850 & 231 & 1663 & & & & & & \\
\hline Sample & 8176 & & & & & & & & & \\
\hline Likelihood & -8931.07 & & & & & & & & & \\
\hline
\end{tabular}


Table A.2. Quantile regression TFP (01/07). Basic model.

\begin{tabular}{llllll}
\hline Exporters & $Q_{y}(0.2 \mid x)$ & $Q_{y}(0.4 \mid x)$ & $Q_{y}(0.6 \mid x)$ & $Q_{y}(0.8 \mid x)$ & Median \\
\hline Constant & $0.249^{* * *}$ & $0.447 * *$ & $0.616 * * *$ & $0.762 * * *$ & $0.534 * * *$ \\
& $(0.006)$ & $(0.010)$ & $(0.007)$ & $(0.006)$ & $(0.009)$ \\
TFP (01/07) & $0.044 * * *$ & $0.069 * * *$ & $0.049 * * *$ & $0.034 * * *$ & $0.060^{* * *}$ \\
& $(0.015)$ & $(0.021)$ & $(0.016)$ & $(0.015)$ & $(0.019)$ \\
Observations & 4365 & & & & \\
\hline FDI & $Q_{y}(0.2 \mid x)$ & $Q_{y}(0.4 \mid x)$ & $Q_{y}(0.6 \mid x)$ & $Q_{y}(0.8 \mid x)$ & Median \\
\hline Constant & $0.139 * *$ & $0.257 * * *$ & $0.426 * * *$ & $0.845 * * *$ & $0.317 * * *$ \\
& $(0.011)$ & $(0.020)$ & $(0.043)$ & $(0.058)$ & $(0.026)$ \\
TFP (01/07) & $0.124 * * *$ & $0.228^{* * *}$ & $0.368 * * *$ & $0.335 * * *$ & $0.294 * *$ \\
& $(0.038)$ & $(0.060)$ & $(0.062)$ & $(0.089)$ & $(0.068)$
\end{tabular}

Observations 548

Note: Standard errors are in parentheses, where $* * *, * *$ and $*$ represent significance at $1 \%, 5 \%$ and $10 \%$ level respectively.

Table A.3. Quantile regression TFP (08/09). Basic model.

\begin{tabular}{llllll}
\hline Exporters & \multicolumn{1}{c}{$Q_{y}(0.2 \mid x)$} & $Q_{y}(0.4 \mid x)$ & $Q_{y}(0.6 \mid x)$ & $Q_{y}(0.8 \mid x)$ & Median \\
\hline Constant & $0.253^{* * *}$ & $0.453^{* * *}$ & $0.616^{* * *}$ & $0.757 * * *$ & $0.537 * * *$ \\
& $(0.007)$ & $(0.011)$ & $(0.007)$ & $(0.06)$ & $(0.009)$ \\
TFP $(08 / 09)$ & $0.045^{* * *}$ & $0.069^{* * *}$ & $0.048^{* * *}$ & $0.029 * *$ & $0.061^{* * *}$ \\
& $(0.014)$ & $(0.019)$ & $(0.016)$ & $(0.014)$ & $(0.019)$ \\
Observations & 3806 & & & & \\
\hline $\boldsymbol{F D I}$ & $Q_{y}(0.2 \mid x)$ & $Q_{y}(0.4 \mid x)$ & $Q_{y}(0.6 \mid x)$ & $Q_{y}(0.8 \mid x)$ & Median \\
\hline Constant & $0.151^{* * *}$ & $0.281^{* * *}$ & $0.496^{* * *}$ & $0.911^{* * *}$ & $0.334 * *$ \\
& $(0.013)$ & $(0.023)$ & $(0.053)$ & $(0.056)$ & $(0.031)$ \\
TFP $(08 / 09)$ & $0.048^{* *}$ & $0.092^{* *}$ & $0.210^{* * *}$ & $0.307 * * *$ & $0.126^{* *}$ \\
& $(0.024)$ & $(0.042)$ & $(0.065)$ & $(0.075)$ & $(0.057)$ \\
Observations & 548 & & & &
\end{tabular}

Note: Standard errors are in parentheses, where $* * *, * *$ and $*$ represent significance at $1 \%, 5 \%$ and $10 \%$ level respectively.

Table A.4. Quantile regression (size and capital intensity). Basic model.

\begin{tabular}{|c|c|c|c|c|c|}
\hline Exporters & $Q_{y}(0.2 \mid x)$ & $Q_{y}(0.4 \mid x)$ & $Q_{y}(0.6 \mid x)$ & $Q_{y}(0.8 \mid x)$ & Median \\
\hline \multirow[t]{2}{*}{ Constant } & 0.067 & $0.172 * *$ & $0.412 * * *$ & $0.594 * * *$ & $0.293 * * *$ \\
\hline & $(0.056)$ & $(0.076)$ & $(0.058)$ & $(0.059)$ & $(0.072)$ \\
\hline \multirow[t]{2}{*}{ Size } & $0.016 * *$ & $0.024 * *$ & $0.018 * * *$ & $0.015^{*}$ & $0.021 * * *$ \\
\hline & $(0.007)$ & $(0.010)$ & $(0.07)$ & $(0.007)$ & $(0.008)$ \\
\hline \multirow[t]{2}{*}{$\mathrm{K} / \mathrm{L}$} & $0.027 * * *$ & $0.041 * * *$ & $0.029 * * *$ & $0.021 * *$ & $0.035 * * *$ \\
\hline & (0.009) & $(0.013)$ & (0.009) & $(0.010)$ & $(0.012)$ \\
\hline Observations & 3402 & & & & \\
\hline$F D I$ & $Q_{y}(0.2 \mid x)$ & $Q_{y}(0.4 \mid x)$ & $Q_{y}(0.6 \mid x)$ & $Q_{y}(0.8 \mid x)$ & Median \\
\hline \multirow[t]{2}{*}{ Constant } & $-0.258^{* *}$ & $-0.408^{* *}$ & $-0.721 * * *$ & $-0.700 * * *$ & $-0.567 * * *$ \\
\hline & $(0.124)$ & $(0.177)$ & $(0.287)$ & $(0.245)$ & $(0.215)$ \\
\hline \multirow[t]{2}{*}{ Size } & $0.047 * * *$ & $0.082 * * *$ & $0.164 * * *$ & $0.228 * * *$ & $0.116 * * *$ \\
\hline & $(0.014)$ & $(0.024)$ & $(0.036)$ & $(0.034)$ & $(0.034)$ \\
\hline \multirow[t]{2}{*}{$\mathrm{K} / \mathrm{L}$} & $0.039 * *$ & $0.063 * *$ & $0.094 * *$ & $0.107 * * *$ & $0.079 * *$ \\
\hline & (0.019) & $(0.025)$ & $(0.048)$ & $(0.036)$ & $(0.032)$ \\
\hline
\end{tabular}

Note: Standard errors are in parentheses, where $* * *, * *$ and $*$ represent significance at $1 \%, 5 \%$ and $10 \%$ level respectively. 


\section{TABLES IN THE MAIN TEXT}

Table 1. Definition of data.

\begin{tabular}{ll}
\hline Variable & Definition \\
\hline TFP (01/07) & Solow residual of a Cobb-Douglas production function estimated following \\
& the semi-parametric algorithm proposed by Levinsohn and Petrin (2003), \\
& $2001-2007$. \\
TFP (08/09) & Solow residual of a Cobb-Douglas production function estimated following \\
the semi-parametric algorithm proposed by Levinsohn and Petrin (2003), \\
\\
2008-2009. \\
Measured in terms of ln(total employment). \\
Size & Natural logarithm of capital labor ratio. \\
HK & Dummy for Human Capital: firm has a higher share of graduate employees \\
& with respect to national average share of graduates. \\
R\&D & Dummy for R\&D: firm employs more than 0 employees in R\&D activities. \\
Centralized & Dummy for centralized/decentralized: It takes a value of 1 if the CEO/owner \\
& makes most of the decisions in every area and 0 if managers can take \\
Age & autonomous decisions in some business areas. \\
\hline Source: EU-EFIGE/Bruegel-UniCredit dataset.
\end{tabular}

Table 2. Descriptive statistics of firm characteristics by internationalization strategy.

\begin{tabular}{llll}
\hline & Domestic & Exporter & FDI \\
\hline Firm (number) & 3402 & 9184 & 719 \\
& 25.569 & 69.072 & 5.404 \\
& & & \\
TFP $(01 / 07)$ & & & -0.192 \\
TFP (08/09) & -0.225 & -0.061 & 0.076 \\
Size & -0.293 & -0.154 & 200.854 \\
K/L & 36.748 & 67.604 & 5.006 \\
HK & 4.371 & 4.807 & 0.269 \\
R\&D & 0.196 & 0.310 & 0.842 \\
Age & 0.397 & 0.671 & 2.678 \\
\hline
\end{tabular}

Source: Authors' calculations based on EFIGE dataset. 
Table 3. Multinomial logit regression of firm strategy decisions (TFP). Extended model

\begin{tabular}{|c|c|c|c|c|c|c|c|c|c|c|}
\hline $\begin{array}{l}\text { Independent } \\
\text { Variables }\end{array}$ & Exporter single & Exporter multi. & FDI single & FDI multi. & $\begin{array}{l}\text { Exporter single } \\
\text { vs } \\
\text { Exporter multi. }\end{array}$ & $\begin{array}{l}\text { FDI single } \\
\text { vs } \\
\text { FDI multi. }\end{array}$ & $\begin{array}{l}\text { Exporter single } \\
\text { vs } \\
\text { FDI single }\end{array}$ & $\begin{array}{l}\text { Exporter single } \\
\text { vs } \\
\text { FDI multi. }\end{array}$ & $\begin{array}{l}\text { Exporter multi. } \\
\text { vs } \\
\text { FDI single }\end{array}$ & $\begin{array}{l}\text { Exporter multi. } \\
\text { vs } \\
\text { FDI multi. }\end{array}$ \\
\hline Constant & $-0.21(0.12)^{*}$ & $-1.96(0.16)^{* * * *}$ & $-4.82(0.37)^{* * *}$ & $-5.96(0.51)^{* * * *}$ & $1.75(0.13) * * *$ & $1.13(0.61)^{*}$ & $4.62(0.36)^{* * *}$ & $5.75(0.51)^{* * *}$ & $2.86(0.38)^{* * *}$ & $4.00(0.51)^{* * *}$ \\
\hline TFP $(01 / 07)$ & $0.47(0.06)^{* * *}$ & $0.75(0.08)^{* * * *}$ & $1.28(0.14)^{* * *}$ & $1.78(0.15) * * *$ & $-0.28(0.06)^{* * * *}$ & $-0.49(0.17) * * *$ & $-0.81(0.13)^{* * *}$ & $-1.30(0.14)^{* * *}$ & $-0.53(0.13)^{* * *}$ & $-1.02(0.14)^{* * * *}$ \\
\hline HK intensity & $0.37(0.06) * * *$ & $0.54(0.07)^{* * * *}$ & $0.29(0.14)^{* *}$ & $0.02(0.16)$ & $-0.17(0.05) * * *$ & $0.27(0.20)$ & $0.08(0.13)$ & $0.35(0.15)^{* *}$ & $0.25(0.14)^{*}$ & $0.52(0.16) * * *$ \\
\hline R\&D intensity & $0.74(0.05) * * *$ & $1.21(0.06)^{* * *}$ & $1.50(0.15)^{* * *}$ & $1.96(0.20)^{* * *}$ & $-0.47(0.05) * * *$ & $-0.46(0.25) *$ & $-0.76(0.15)^{* * *}$ & $-1.22(0.20)^{* * *}$ & $-0.29(0.15)^{*}$ & $-0.75(0.20)^{* * * *}$ \\
\hline Centralized & $-0.26(0.06) * * *$ & $-0.03(0.07)$ & $-0.58(0.13) * * *$ & $-0.88(0.14)^{* * * *}$ & $-0.23(0.05) * * *$ & $0.29(0.18)^{*}$ & $0.32(0.12)^{* * *}$ & $0.62(0.13)^{* * *}$ & $0.55(0.13)^{* * *}$ & $0.85(0.14)^{* * *}$ \\
\hline Age & $0.27(0.04) * * *$ & $0.39(0.05)^{* * * *}$ & $0.68(0.12) * * *$ & $0.87(0.15) * * *$ & $-0.12(0.04) * * *$ & $-0.59(0.15) * * *$ & $-0.40(0.12)^{* * *}$ & $-0.59(0.15)^{* * *}$ & $-0.28(0.12)^{* * *}$ & $-0.47(0.15)^{* * * *}$ \\
\hline $\begin{array}{l}\text { Industry fixed } \\
\text { effects }\end{array}$ & yes & yes & yes & yes & yes & yes & yes & yes & yes & yes \\
\hline Observations & 5110 & 2218 & 276 & 238 & & & & & & \\
\hline Sample & 9869 & & & & & & & & & \\
\hline Likelihood & -10937.18 & & & & & & & & & \\
\hline Constant & $-0.23(0.13)^{*}$ & $-2.19(0.17) * * *$ & $-5.21(0.41)^{* * * *}$ & $-5.83(0.55) * * *$ & $1.95(0.14) * * *$ & $0.62(0.67)$ & $4.97(0.40)^{* * *}$ & $5.59(0.51)^{* * *}$ & $3.02(0.41)^{* * *}$ & $3.64(0.55)^{* * *}$ \\
\hline TFP $(08 / 09)$ & $0.32(0.05)^{* * *}$ & $0.46(0.06) * * *$ & $0.85(0.15)^{* * *}$ & $1.17(0.13)^{* * *}$ & $-0.14(0.05)^{* * *}$ & $-0.31(0.17) *$ & $0.53(0.14)^{* * * *}$ & $-0.84(0.12)^{* * *}$ & $-0.39(0.14)^{* * *}$ & $-0.70(0.13)^{* * * *}$ \\
\hline HK intensity & $0.35(0.06)^{* * *}$ & $0.54(0.07)^{* * * *}$ & $0.21(0.15)$ & $-0.02(0.18)$ & $-0.18(0.05) * * *$ & $0.23(0.21)$ & $0.13(0.14)$ & $0.37(0.17)^{* *}$ & $0.3(0.15)^{* * *}$ & $0.56(0.17)^{* * *}$ \\
\hline R\&D intensity & $0.76(0.05)^{* * *}$ & $1.28(0.07)^{* * *}$ & $1.51(0.14)^{* * *}$ & $2.18(0.23)^{* * *}$ & $-0.51(0.06)^{* * *}$ & $0.66(0.28) * *$ & $-0.75(0.16)^{* * *}$ & $-1.41(0.23)^{* * *}$ & $-0.23(0.17)$ & $-0.90(0.23) * * *$ \\
\hline Centralized & $-0.20(0.06)^{* * *}$ & $0.01(0.07)$ & $-0.51(0.14)^{* * *}$ & $-0.88(0.15)^{* * *}$ & $-0.21(0.06)^{* * *}$ & $0.37(0.19) *$ & $0.30(0.13)^{* *}$ & $0.67(0.15)^{* * *}$ & $0.51(0.14)^{* * *}$ & $0.89(0.15)^{* * *}$ \\
\hline Age & $0.28(0.04)^{* * *}$ & $0.46(0.05)^{* * * *}$ & $0.84(0.13)^{* * *}$ & $0.82(0.16)^{* * *}$ & $-0.18(0.04) * * *$ & $0.02(0.20)$ & $-0.55(0.13) * * *$ & $-0.53(0.16) * * *$ & $-0.37(0.13) * * *$ & $-0.35(0.16)^{* *}$ \\
\hline $\begin{array}{l}\text { Industry fixed } \\
\text { effects }\end{array}$ & yes & yes & yes & yes & yes & yes & yes & yes & yes & yes \\
\hline Observations & 4261 & 1931 & 235 & 199 & & & & & & \\
\hline Sample & 8804 & & & & & & & & & \\
\hline Likelihood & -9699.58 & & & & & & & & & \\
\hline
\end{tabular}


Table 4. Multinomial logit regression of firm strategy decisions (size and capital intensity).

\begin{tabular}{|c|c|c|c|c|c|c|c|c|c|c|}
\hline $\begin{array}{l}\text { Independent } \\
\text { Variables }\end{array}$ & Exporter single & Exporter multi. & FDI single & FDI multi. & $\begin{array}{c}\text { Exporter single } \\
\text { vs } \\
\text { Exporter multi. }\end{array}$ & $\begin{array}{c}\begin{array}{c}\text { FDI single } \\
\text { vs } \\
\text { FDI multi. }\end{array} \\
\end{array}$ & $\begin{array}{l}\text { Exporter single } \\
\text { vs } \\
\text { FDI single }\end{array}$ & $\begin{array}{l}\text { Exporter single } \\
\text { vs } \\
\text { FDI multi. }\end{array}$ & $\begin{array}{l}\text { Exporter multi. } \\
\text { vs } \\
\text { FDI single }\end{array}$ & $\begin{array}{l}\text { Exporter multi. } \\
\text { vs } \\
\text { FDI multi. }\end{array}$ \\
\hline Constant & $-1.66(0.14)^{* * * *}$ & $-3.73(0.16)^{* * *}$ & $-8.95(0.36)^{* * *}$ & $-10.84(0.50)^{* * * *}$ & $2.06(0.13)^{* * *}$ & $1.89(0.57)^{* * * *}$ & $7.28(0.34)^{* * * *}$ & $9.18(0.49)^{* * * *}$ & $5.21(0.34)^{* * * *}$ & $7.11(0.49)^{* * * *}$ \\
\hline Size & $0.46(0.03) * * *$ & $0.59(0.03)^{* * *}$ & $1.27(0.05)^{* * *}$ & $1.48(0.06)^{* * *}$ & $-0.13(0.02)^{* * *}$ & $-0.21(0.07)^{* * *}$ & $-0.80(0.04)^{* * *}$ & $-1.02(0.05)^{* * *}$ & $-0.67(0.04)^{* * *}$ & $-0.89(0.05)^{* * *}$ \\
\hline HK intensity & $0.50(0.05)^{* * *}$ & $0.70(0.06)^{* * *}$ & $0.82(0.12)^{* * *}$ & $0.62(0.15) * * *$ & $-0.20(0.04)^{* * *}$ & $0.19(0.18)$ & $-0.31(0.12)^{* * *}$ & $-0.11(0.14)$ & $-0.11(0.12)$ & $0.08(0.14)$ \\
\hline$R \& D$ intensity & $0.60(0.04)^{* * * *}$ & $1.11(0.05)^{* * *}$ & $1.15(0.14)^{* * * *}$ & $1.55(0.18)^{* * *}$ & $-0.51(0.04)^{* * *}$ & $-0.39(0.22)^{*}$ & $-0.55(0.13)^{* * *}$ & $-0.95(0.18)^{* * * *}$ & $-0.04(0.14)$ & $-0.43(0.18)^{* *}$ \\
\hline Centralized & $-0.24(0.05) * * *$ & $-0.11(0.06)^{*}$ & $-0.49(0.11)^{* * *}$ & $-0.76(0.12)^{* * *}$ & $-0.12(0.04)^{* * * *}$ & $0.26(0.15)^{*}$ & $0.25(0.11)^{* *}$ & $0.51(0.12) * * *$ & $0.38(0.11)^{* * *}$ & $0.64(0.12)^{* * *}$ \\
\hline Age & $0.19(0.03) * * *$ & $0.30(0.04)^{* * * *}$ & $0.41(0.09) * * *$ & $0.55(0.12) * * *$ & $-0.10(0.03) * * *$ & $-0.13(0.14)$ & $-0.22(0.09)^{* * *}$ & $-0.36(0.11)^{* * *}$ & $-0.11(0.09)$ & $-0.25(0.11)^{* *}$ \\
\hline $\begin{array}{l}\text { Industry fixed } \\
\text { effects }\end{array}$ & yes & yes & yes & yes & yes & yes & yes & yes & yes & yes \\
\hline $\begin{array}{l}\text { Observations } \\
\text { Sample } \\
\text { Likelihood }\end{array}$ & $\begin{array}{l}7185 \\
14235 \\
-15713.39\end{array}$ & 3453 & 397 & 319 & & & & & & \\
\hline Constant & $-1.66(0.21)^{* * * *}$ & $-4.87(0.28)^{* * * *}$ & $-7.89(0.66) * * *$ & $-9.88(0.71) * * *$ & $3.20(0.22)^{* * *}$ & $1.98(0.90)^{* *}$ & $6.23(0.63) * * *$ & $8.22(0.68) * * *$ & $3.02(0.64)^{* * * *}$ & $5.01(0.69)^{* * * *}$ \\
\hline $\mathrm{K} / \mathrm{L}$ & $0.36(0.03) * * *$ & $0.68(0.04)^{* * *}$ & $0.66(0.11)^{* * * *}$ & $0.92(0.08)^{* * *}$ & $-0.31(0.03)^{* * *}$ & $-0.25(0.12)^{* *}$ & $-0.30(0.10)^{* * *}$ & $-0.55(0.08)^{* * *}$ & $0.01(0.10)$ & $-0.24(0.08) * * *$ \\
\hline HK intensity & $0.24(0.07)^{* * *}$ & $0.32(0.08)^{* * *}$ & $0.07(0.16)$ & $-0.36(0.18)^{*}$ & $-0.07(0.06)$ & $0.43(0.22)^{*}$ & $0.17(0.15)$ & $0.60(0.17)^{* * *}$ & $0.24(0.15)$ & $0.68(0.17)^{* * *}$ \\
\hline$R \& D$ intensity & $0.77(0.06)^{* * *}$ & $1.23(0.07)^{* * * *}$ & $1.56(0.17)^{* * * *}$ & $2.29(0.24)^{* * * *}$ & $-0.45(0.06)^{* * * *}$ & $-0.73(0.29)^{* *}$ & $-0.78(0.17)^{* * *}$ & $-1.51(0.23) * * *$ & $-0.33(0.17)^{*}$ & $-1.06(0.24)^{* * *}$ \\
\hline Centralized & $-0.32(0.07) * * *$ & $-0.15(0.08)^{*}$ & $-0.69(0.15)^{* * *}$ & $-1.14(0.16)^{* * *}$ & $-0.16(0.06)^{* * *}$ & $0.44(0.20)^{* *}$ & $0.36(0.14)^{* * * *}$ & $0.81(0.15)^{* * *}$ & $0.53(0.14)^{* * * *}$ & $0.98(0.15)^{* * * *}$ \\
\hline Age & $0.22(0.04) * * *$ & $0.35(0.06)^{* * *}$ & $0.71(0.13)^{* * * *}$ & $0.72(0.16)^{* * *}$ & $-0.13(0.05)^{* * *}$ & $-0.01(0.20)$ & $-0.48(0.13)^{* * *}$ & $-0.50(0.16)^{* * *}$ & $-0.35(0.13) * * *$ & $-0.36(0.16)^{* *}$ \\
\hline $\begin{array}{l}\text { Industry fixed } \\
\text { effects }\end{array}$ & yes & yes & yes & yes & yes & yes & yes & yes & yes & yes \\
\hline Observations & 4227 & 1850 & 231 & 205 & & & & & & \\
\hline Sample & 7866 & & & & & & & & & \\
\hline Likelihood & -8697.97 & & & & & & & & & \\
\hline Constant & $-3.19(0.25)^{* * *}$ & $-6.88(0.31)^{* * *}$ & $-11.97(0.70)^{* * *}$ & $-14.32(0.82)^{* * * *}$ & $3.69(0.23)^{* * *}$ & $2.34(0.96)^{* *}$ & $8.78(0.65)^{* * * *}$ & $11.12(0.79)^{* * * *}$ & $5.08(0.65) * * *$ & $7.43(0.78)^{* * *}$ \\
\hline Size & $0.49(0.04)^{* * *}$ & $0.66(0.04)^{* * *}$ & $1.35(0.07)^{* * *}$ & $1.48(0.08)^{* * *}$ & $-0.16(0.03)^{* * *}$ & $-0.13(0.09)$ & $-0.85(0.06)^{* * *}$ & $-0.98(0.07)^{* * *}$ & $-0.68(0.06)^{* * *}$ & $-0.81(0.07)^{* * *}$ \\
\hline $\mathrm{K} / \mathrm{L}$ & $0.34(0.03)^{* * * *}$ & $0.65(0.04)^{* * * *}$ & $0.57(0.11)^{* * *}$ & $0.79(0.09)^{* * *}$ & $-0.30(0.03) * * *$ & $-0.22(0.12)^{*}$ & $-0.22(0.10)^{* *}$ & $-0.44(0.08)^{* * *}$ & $0.08(0.10)$ & $0.15(0.08)^{*}$ \\
\hline HK intensity & $0.40(0.07)^{* * * *}$ & $0.55(0.08)^{* * *}$ & $0.68(0.17)^{* * *}$ & $0.34(0.19)^{*}$ & $-0.15(0.06)^{* * *}$ & $0.34(0.23)$ & $-0.28(0.16)^{*}$ & $0.05(0.18)$ & $-0.12(0.16)$ & $0.21(0.18)$ \\
\hline$R \& D$ intensity & $0.65(0.06)^{* * * *}$ & $1.04(0.07)^{* * *}$ & $1.05(0.18)^{* * *}$ & $1.73(0.25)^{* * *}$ & $-0.39(0.06)^{* * *}$ & $-0.67(0.29)^{* *}$ & $-0.40(0.17)^{* *}$ & $-1.08(0.24)^{* * *}$ & $-0.01(0.18)$ & $-0.69(0.24) * * *$ \\
\hline Centralized & $-0.21(0.07)^{* * *}$ & $0.01(0.08)$ & $-0.29(0.16)^{* *}$ & $-0.70(0.16)^{* * *}$ & $-0.22(0.06)^{* * *}$ & $0.40(0.20)^{* *}$ & $0.08(0.14)$ & $0.49(0.15)^{* * *}$ & $0.31(0.15)^{* *}$ & $0.71(0.15)^{* * *}$ \\
\hline Age & $0.16(0.04)^{* * *}$ & $0.26(0.06)^{* * *}$ & $0.45(0.13)^{* * *}$ & $0.41(0.16)^{* * *}$ & $-0.10(0.05)^{* *}$ & $0.03(0.19)$ & $-0.29(0.13)^{* *}$ & $-0.25(0.15)^{*}$ & $-0.19(0.13)$ & $-0.15(0.15)$ \\
\hline $\begin{array}{l}\text { Industry fixed } \\
\text { effects }\end{array}$ & yes & yes & yes & yes & yes & yes & yes & yes & yes & yes \\
\hline Observations & 4078 & 1769 & 218 & 199 & & & & & & \\
\hline Sample & 7866 & & & & & & & & & \\
\hline Likelihood & -8405.24 & & & & & & & & & \\
\hline
\end{tabular}


Table 5. Quantile regression TFP (01/07). Extended model.

\begin{tabular}{|c|c|c|c|c|c|}
\hline Exporters & $Q_{y}(0.2 \mid x)$ & $Q_{y}(0.4 \mid x)$ & $Q_{y}(0.6 \mid x)$ & $Q_{y}(0.8 \mid x)$ & Median \\
\hline \multirow[t]{2}{*}{ Constant } & $0.183 * * *$ & $0.319 * * *$ & $0.435 * * *$ & $0.604 * * *$ & $0.352 * * *$ \\
\hline & $(0.033)$ & $(0.043)$ & $(0.042)$ & $(0.037)$ & $(0.042)$ \\
\hline \multirow[t]{2}{*}{ TFP (01/07) } & $0.032 * *$ & $0.040 * *$ & 0.025 & 0.023 & 0.025 \\
\hline & $(0.015)$ & $(0.019)$ & $(0.016)$ & $(0.016)$ & $(0.017)$ \\
\hline \multirow[t]{2}{*}{ HK } & $0.041 * * *$ & $0.056 * * *$ & $0.046 * * *$ & $0.031 *$ & $0.055 * * *$ \\
\hline & $(0.016)$ & $(0.020)$ & $(0.016)$ & $(0.017)$ & $(0.018)$ \\
\hline \multirow[t]{2}{*}{$\mathrm{R} \& \mathrm{D}$} & $0.109 * * *$ & $0.174 * * *$ & $0.145 * * *$ & $0.073 * * *$ & $0.183 * * *$ \\
\hline & $(0.013)$ & $(0.020)$ & $(0.021)$ & $(0.016)$ & $(0.022)$ \\
\hline \multirow[t]{2}{*}{ Centralized } & $-0.039 * *$ & $-0.047 * *$ & $-0.032 * *$ & -0.021 & $-0.039 * *$ \\
\hline & $(0.017)$ & $(0.020)$ & $(0.016)$ & $(0.019)$ & $(0.019)$ \\
\hline \multirow[t]{2}{*}{ Age } & 0.004 & 0.010 & $0.030 * *$ & $0.042 * * *$ & 0.020 \\
\hline & $(0.011)$ & $(0.015)$ & $(0.013)$ & $(0.012)$ & $(0.014)$ \\
\hline Observations & 4211 & & & & \\
\hline$F D I$ & $Q_{y}(0.2 \mid x)$ & $Q_{y}(0.4 \mid x)$ & $Q_{y}(0.6 \mid x)$ & $Q_{y}(0.8 \mid x)$ & Median \\
\hline \multirow[t]{2}{*}{ Constant } & 0.095 & 0.191 & 0.256 & 0.256 & 0.249 \\
\hline & $(0.084)$ & $(0.150)$ & (0.197) & $(0.219)$ & $(0.176)$ \\
\hline \multirow[t]{2}{*}{ TFP (01/07) } & $0.114 * * *$ & $0.198 * * *$ & $0.283 * * *$ & $0.281 * * *$ & $0.255^{* * * *}$ \\
\hline & $(0.039)$ & $(0.062)$ & $(0.080)$ & $(0.090)$ & $(0.069)$ \\
\hline \multirow[t]{2}{*}{ HK } & -0.031 & -0.052 & -0.117 & -0.090 & -0.080 \\
\hline & $(0.029)$ & $(0.050)$ & $(0.086)$ & $(0.128)$ & $(0.062)$ \\
\hline \multirow[t]{2}{*}{ R\&D } & $0.057 * *$ & $0.108 * *$ & $0.230 * * *$ & $0.364 * * *$ & $0.145 * *$ \\
\hline & $(0.028)$ & $(0.049)$ & $(0.079)$ & $(0.126)$ & $(0.063)$ \\
\hline \multirow[t]{2}{*}{ Centralized } & -0.045 & -0.073 & $-0.141 *$ & -0.099 & -0.101 \\
\hline & $(0.029)$ & $(.050)$ & $(0.084)$ & $(0.108)$ & $(0.067)$ \\
\hline \multirow[t]{2}{*}{ Age } & 0.014 & 0.016 & 0.046 & $0.126^{*}$ & 0.018 \\
\hline & $(0.026)$ & $(0.047)$ & $(0.068)$ & $(0.076)$ & $(0.057)$ \\
\hline
\end{tabular}

Note: Standard errors are in parentheses, where $* * *, * *$ and $*$ represent significance at $1 \%, 5 \%$ and $10 \%$ level respectively. 
Table 6. Quantile regression TFP (08/09). Extended model.

\begin{tabular}{|c|c|c|c|c|c|}
\hline Exporters & $Q_{y}(0.2 \mid x)$ & $Q_{y}(0.4 \mid x)$ & $Q_{y}(0.6 \mid x)$ & $Q_{y}(0.8 \mid x)$ & Median \\
\hline \multirow[t]{2}{*}{ Constant } & $0.165 * * *$ & $0.293 * * *$ & $0.395 * * *$ & $0.568 * * *$ & $0.323 * * *$ \\
\hline & $(0.035)$ & $(0.046)$ & $(0.046)$ & $(0.038)$ & $(0.043)$ \\
\hline \multirow[t]{2}{*}{ TFP (08/09) } & $0.031 * *$ & $0.039 * *$ & $0.028 *$ & 0.023 & $0.031 *$ \\
\hline & $(0.014)$ & $(0.018)$ & $(0.016)$ & $(0.014)$ & $(0.017)$ \\
\hline \multirow[t]{2}{*}{ HK } & $0.044 * * *$ & $0.060 * * *$ & $0.055^{* * *}$ & $0.041 * *$ & $0.061 * * *$ \\
\hline & $(0.017)$ & $(0.020)$ & $(0.016)$ & $(0.018)$ & $(0.019)$ \\
\hline \multirow[t]{2}{*}{$\mathrm{R} \& \mathrm{D}$} & $0.121 * * *$ & $0.192 * * *$ & $0.168 * * *$ & $0.087 * * *$ & $0.201 * * *$ \\
\hline & $(0.014)$ & $(0.021)$ & $(0.024)$ & $(0.017)$ & $(0.022)$ \\
\hline \multirow[t]{2}{*}{ Centralized } & $-0.038 * *$ & $-0.045 * *$ & -0.028 & -0.015 & $-0.034 *$ \\
\hline & $(0.018)$ & $(0.021)$ & $(0.017)$ & $(0.020)$ & $(0.019)$ \\
\hline \multirow[t]{2}{*}{ Age } & 0.009 & $0-016$ & $0.035 * * *$ & $0.047 * * *$ & $0.025^{*}$ \\
\hline & $(0.012)$ & $(0.016)$ & $(0.014)$ & $(0.012)$ & $(0.014)$ \\
\hline Observations & 3672 & & & & \\
\hline$F D I$ & $Q_{y}(0.2 \mid x)$ & $Q_{y}(0.4 \mid x)$ & $Q_{y}(0.6 \mid x)$ & $Q_{y}(0.8 \mid x)$ & Median \\
\hline \multirow[t]{2}{*}{ Constant } & 0.153 & 0.259 & $0.315^{*}$ & 0.204 & $0.322 *$ \\
\hline & $(0.102)$ & $(0.172)$ & $(0.195)$ & $(0.257)$ & $(0.184)$ \\
\hline \multirow[t]{2}{*}{ TFP (08/09) } & 0.040 & $0.080 *$ & $0.189 * * *$ & $0.255 * * *$ & $0.129 * *$ \\
\hline & $(0.025)$ & $(0.046)$ & $(0.050)$ & $(0.048)$ & $(0.057)$ \\
\hline \multirow[t]{2}{*}{ HK } & -0.024 & -0.046 & -0.110 & -0.071 & -0.068 \\
\hline & $(0.032)$ & $(0.056)$ & $(0.088)$ & $(0.142)$ & $(0.073)$ \\
\hline \multirow[t]{2}{*}{$\mathrm{R} \& \mathrm{D}$} & $0.084 * * *$ & $0.152^{* * *}$ & $0.324 * * *$ & $0.458 * * *$ & $0.214 * * *$ \\
\hline & $(0.029)$ & $(0.049)$ & $(0.082)$ & $(0.154)$ & $(0.066)$ \\
\hline \multirow[t]{2}{*}{ Centralized } & -0.049 & -0.083 & $-0.173 * *$ & -0.139 & $-0.147 *$ \\
\hline & $(0.032)$ & $(0.055)$ & $(0.087)$ & $(0.108)$ & $(0.082)$ \\
\hline \multirow[t]{2}{*}{ Age } & -0.010 & -0.011 & 0.023 & $0.146^{*}$ & -0.004 \\
\hline & $\begin{array}{l}(0.033) \\
447\end{array}$ & $(0.056)$ & $(0.063)$ & $(0.257)$ & $(0.063)$ \\
\hline
\end{tabular}


Table 7. Quantile regression (size and capital intensity). Extended model.

\begin{tabular}{|c|c|c|c|c|c|}
\hline Exporters & $Q_{y}(0.2 \mid x)$ & $Q_{y}(0.4 \mid x)$ & $Q_{y}(0.6 \mid x)$ & $Q_{y}(0.8 \mid x)$ & Median \\
\hline \multirow[t]{2}{*}{ Constant } & 0.075 & $0.187 * *$ & $0.333 * * *$ & $0.492 * * *$ & $0.245^{* * *}$ \\
\hline & $(0.064)$ & $(0.081)$ & $(0.074)$ & $(0.071)$ & $(0.076)$ \\
\hline \multirow[t]{2}{*}{ Size } & 0.003 & 0.004 & 0.005 & 0.007 & 0.004 \\
\hline & $(0.008)$ & $(0.010)$ & $(0.008)$ & $(0.008)$ & $(0.009)$ \\
\hline \multirow[t]{2}{*}{$\mathrm{K} / \mathrm{L}$} & $0.019 * *$ & $0.025 * *$ & $0.022 * *$ & $0.196^{*}$ & $0.024 * *$ \\
\hline & $(0.009)$ & $(0.012)$ & $(0.010)$ & $(0.011)$ & $(0.011)$ \\
\hline \multirow[t]{2}{*}{ HK } & $0.038 * *$ & $0.047 * *$ & $0.042 * * *$ & $0.036 *$ & $0.049 * *$ \\
\hline & $(0.019)$ & $(0.023)$ & $(0.017)$ & $(0.020)$ & $(0.020)$ \\
\hline \multirow[t]{2}{*}{$\mathrm{R} \& \mathrm{D}$} & $0.111 * * *$ & $0.170 * * *$ & $0.124 * * *$ & $0.058 * * *$ & $0.163 * * *$ \\
\hline & $(0.016)$ & $(0.023)$ & $(0.023)$ & $(0.018)$ & $(0.025)$ \\
\hline \multirow[t]{2}{*}{ Centralized } & $-0.047 * *$ & $-0.053 * *$ & $-0.040 * *$ & -0.032 & $-0.048 * *$ \\
\hline & $(0.020)$ & $(0.022)$ & $(0.017)$ & $(0.020)$ & $(0.020)$ \\
\hline \multirow[t]{2}{*}{ Age } & 0.010 & 0.015 & $0.030 * *$ & $0.042 * * *$ & 0.023 \\
\hline & $(0.014)$ & $(0.017)$ & $(0.013)$ & $(0.012)$ & $(0.015)$ \\
\hline Observations & 3276 & & & & \\
\hline$F D I$ & $Q_{y}(0.2 \mid x)$ & $Q_{y}(0.4 \mid x)$ & $Q_{y}(0.6 \mid x)$ & $Q_{y}(0.8 \mid x)$ & Median \\
\hline \multirow[t]{2}{*}{ Constant } & -0.134 & -0.266 & $-0.674 * *$ & $-0.965 * * *$ & -0.431 \\
\hline & $(0.167)$ & $(0.259)$ & $(0.303)$ & $(0.315)$ & $(0.291)$ \\
\hline \multirow[t]{2}{*}{ Size } & $0.035 * *$ & $0.064 * *$ & $0.116 * * *$ & $0.211 * * *$ & $0.087 * *$ \\
\hline & $(0.016)$ & $(0.028)$ & $(0.041)$ & $(0.043)$ & $(0.035)$ \\
\hline \multirow[t]{2}{*}{$\mathrm{K} / \mathrm{L}$} & $0.034 *$ & $0.059 * *$ & $0.095 * * *$ & $0.086^{*}$ & $0.77 * * *$ \\
\hline & $(0.019)$ & $(0.025)$ & $(0.034)$ & $(0.050)$ & $(0.030)$ \\
\hline \multirow[t]{2}{*}{ HK } & -0.025 & -0.059 & -0.103 & -0.040 & -0.088 \\
\hline & $(0.037)$ & $(0.061)$ & $(0.109)$ & $(0.113)$ & $(0.079)$ \\
\hline \multirow[t]{2}{*}{ R\&D } & $0.078 * *$ & $0.147 * * *$ & $0.265 * * *$ & 0.257 & $0.201 * * *$ \\
\hline & $(0.033)$ & $(0.057)$ & $(0.091)$ & $(0.168)$ & $(0.073)$ \\
\hline \multirow[t]{2}{*}{ Centralized } & $-0.067 *$ & $-0.121 * *$ & $-0.187 * *$ & $-0.177 *$ & $-0.169 * *$ \\
\hline & $(0.035)$ & $(0.060)$ & $(0.090)$ & $(0.097)$ & $(0.081)$ \\
\hline \multirow[t]{2}{*}{ Age } & -0.017 & -0.021 & 0.034 & 0.123 & -0.002 \\
\hline & $(0.035)$ & $(0.052)$ & $(0.061)$ & $(0.086)$ & $(0.291)$ \\
\hline Observations & 433 & & & & \\
\hline
\end{tabular}

Note: Standard errors are in parentheses, where $* * *, * *$ and $*$ represent significance at $1 \%, 5 \%$ and $10 \%$ level respectively. 